\title{
A Review of Effect of Different Tasks on Incidental Vocabulary
} Acquisition

\author{
Chen L. Liu ${ }^{1}$ \\ ${ }^{1}$ School of Foreign Studies, Nantong University, Nantong, China \\ Correspondence: Chen L. Liu, School of Foreign Studies, Nantong University, Nantong, Jiangsu, 226000, China. \\ E-mail: stellaxingchen@ntu.edu.cn
}

Received: August 27, 2015

Accepted: September 22, 2015 Online Published: September 28, 2015

doi:10.5539/hes.v5n5p56

URL: http://dx.doi.org/10.5539/hes.v5n5p56

\begin{abstract}
Studies of incidental vocabulary acquisition in second language learning have got more and more attention both at home and abroad. By first introducing the definition and theoretical foundations of incidental vocabulary acquisition, this paper reviews empirical studies of effect of different tasks on incidental vocabulary acquisition and points out new perspective for further study in order to help Chinese English learners acquire vocabulary more effectively.
\end{abstract}

Keywords: incidental vocabulary acquisition, different tasks, empirical studies

\section{Introduction}

Vocabulary acquisition is a necessary part, yet a difficult problem in second language acquisition. Researchers tried to find an effective way to enlarge the learners' vocabulary. Since the term "incidental vocabulary acquisition" was first put forward, many researchers have discussed its importance in second language acquisition. The author has been teaching English for more than ten years and knows that many students have difficulties in memorizing the new words. However, the author is clearly aware that it is unrealistic for students to read and memorize the new words all the time. Thus, it arouses the author's interest to make a review of effect of different tasks on incidental vocabulary acquisition in order to provide Chinese English learners with some useful suggestions on how to facilitate vocabulary acquisition more effectively. What's more, it can also offer English teachers valuable suggestions.

\section{Theoretical Foundations in the Study of Incidental Vocabulary Acquisition}

\subsection{Depth of Processing Model}

The term "incidental vocabulary acquisition" was first put forward by Nagy, Herman and Anderson in 1985 when they studied children's L1 vocabulary acquisition. They propose that the vast majority of vocabulary words are learned gradually through repeated exposures in various contexts. Since then, researchers have made a lot of studies to prove that learners can actually acquire a certain amount of new words when they are doing other language activities rather than memorizing the new words directly. In order to explain the empirical studies of incidental vocabulary acquisition, Craik and Lockhart (1972) proposed "Depth of processing Model", which states that "the memory trace can be understood as a by-product of perceptual analysis and that trace persistence is a positive function of the depth to which the stimulus has been analyzed" (1972, p. 671). The level or depth of processing of a stimulus has a large effect on its memorability and deeper analysis produces more elaborate, longer lasting and stronger memory traces. This theory considers that there are two forms of cognitive processing: formative and semantic processing. The former is at a shallow level of analysis while the latter is at a deep level. For example, processing the meaning of a new lexical item takes place at a rather deep level while processing the phonological form takes place at a rather shallow level. Learners can have a better retention of the new information if they can process it at a deep level. Therefore, in terms of incidental vocabulary acquisition, if learners have a deep processing of the new words, they can have a better retention of those words. However, Craik and Lockhart's model has one problem which is that their perspective on depth of processing is too simple. The memory of words is affected by other factors in addition to orthographical, acoustic, and semantic information which should be classified into more than three levels of memory trace (Mayumi, 2006). 


\subsection{The Involvement Load Hypothesis}

With the deep study of incidental vocabulary acquisition, Laufer and Hulstijn (2001) proposed "Involvement Load Hypothesis" which explains the incidental vocabulary acquisition from the angle of cognitive psychology. It claims that the amount of involvement in the tasks that the learners are engaged in will affect the retention of unfamiliar words. Involvement load has three components: need, search and evaluation. Need is a motivational, non-cognitive dimension of involvement whereas search and evaluation are from the cognitive dimension. Need is the motivation to learn the target words. For example, when a learner is reading a passage and comes across an unknown word which affects the comprehension, he or she will experience the need to understand it. Search occurs when the learner has to look for the meanings of the target words, for instance, the learners have to look up in a dictionary or ask the teachers to find the meanings of the target words. Evaluation means a "comparison of a given word with other words, a specific meaning of a word with other meanings or combining the words in order to assess whether a word (i.e. a form-meaning pair) does or does not fit its context" (Laufer \& Hulstijn, 2001, p. 14). For example, while you are reading, an unknown word that you look up in the dictionary is a homonym. Then you have to decide which meaning best fits the context by comparing all its meanings against the specific context. The two researchers not only come up with the three components but also they suggest three degrees of value for each component: none, moderate and strong. Each level is clearly described in Table 1.

Table 1. The degrees of the components in the Involvement Load Hypothesis

\begin{tabular}{ll}
\hline Components & Degrees of the Involvement Load \\
\hline Need & Index 0 (None) \\
& Index 1 (Moderate) \\
& Index 2 (Strong) \\
\hline Search & Index 0 (None) \\
& Index 1 (Moderate) \\
& Index 2 (Strong) \\
\hline Evaluation & Index 0 (None) \\
& Index 1 (Moderate) \\
& Index 2 (Strong) \\
\hline
\end{tabular}

For example, a reading comprehension task with glossed words will induce a moderate need (moderate because the reader has to look at the glosses), but it will induce neither search nor evaluation. Thus the involvement load of the task is $1(1+0+0)$. However, if the learner is asked to make sentences with some new words which are translated or explained by the teacher, the task induces a moderate need, no search and strong evaluation. The reason is that the words are assessed by the learners themselves. Therefore, the involvement load of the task is $3(1+0+2)$.

In general, tasks that induce strong levels of need, search, and evaluation of meanings of unfamiliar words are most effective for vocabulary acquisition.

\subsection{Pushed Output Hypothesis}

Pushed output hypothesis was proposed by Swain (1985). The hypothesis predicts that we acquire language when there is a communicative breakdown and we are pushed to use alternative means to get across the message precisely, coherently, and appropriately. When learners produce pushed output they are able to develop greater control over the features they have already acquired. And pushed output can stimulate the learners to deal with the output which may lead to greater metalinguistic awareness effectively for their greater interlanguage development. In the process of striving to produce output that their interlocutors will understand, learners may pay particular attention to form as well as notice a gap between what they want to say and what they can say, leading them to recognize what they do not know, or know only partially (Izumi \& Bigelow, 2000). Output plays an important role in the acquisition of syntax and words. Ellis and He (1999) points out that output is more effective in vocabulary acquisition than input. 


\section{Studies of Effect of Different Tasks on Incidental Vocabulary Acquisition}

\subsection{Studies of Effect of Reading on Incidental Vocabulary Acquisition}

According to Gai (2003a), studies of incidental vocabulary acquisition enhanced by reading were largely conducted, because it was widely accepted that reading was an effective way to enlarge learners' vocabulary. Many researchers had conducted experiments to illustrate the effect of reading task on incidental vocabulary acquisition.

Nagy, Harman and Anderson (1985), Nagy and Harman (1987) argued that American high school students couldn't have learned vast number of words merely by means of clear vocabulary instruction. They must have learned most of the words through repeated encounters in extensive reading, because relatively few words were explicitly taught, most words must have been acquired from reading.

Elley (1991) launched the experiment of "book flood", which lasted a long time, from 12 months to 36 months. The participants, ranged from six to twelve years old, were asked to read some books which were required to read in English-speaking countries. After two years, the participants' oral expression, reading comprehension, and writing abilities are improved as well as their size of vocabulary.

Knight (1994) made a comparison between good students and poor students in terms of their ability of word guessing and retention while reading. It turned out that guessing the meaning of the new words according to the context was useful for learners to acquire vocabulary.

In Cho and Krashen's (1994) experiment, one of the four subjects acquired seven words from a book without using a dictionary. The second subject acquired eight words by using the dictionary for a while. The other two subjects used the dictionary all the time and even wrote the words with example sentences (though they were not trying to memorize these words on purpose). These two subjects acquired 17 and 34 words per book. Therefore, the experiment showed that dictionary use led to better vocabulary learning than reading only.

In another kind of vocabulary study by Paribakht and Wesche (1996), students in a group who were given vocabulary questions following a reading demonstrated greater productive knowledge of target words than a comparable group presented with comprehension instead.

Laufer and Hulstijn (2001) put forward "Involvement Load Hypothesis". They thought that vocabulary incidentally acquired while reading had a lot to do with the reading tasks, because the learners made different effort towards different tasks. To prove this, they made experiments in New Zealand and Israel respectively. The participants were divided into three groups and were asked to finish three tasks: reading comprehension, reading comprehension plus cloze (using the target words) and writing a composition by using the target words. Immediate and delayed vocabulary tests were conducted. It turned out that students who wrote a composition got the target words better than the two other groups, which proved the Involvement Load Hypothesis because the students in this group made the greatest effort in order to finish the task.

Swanborn and de Glopper (2002) studied the relationship between reading ability, reading purpose and incidental vocabulary acquisition from context. Two hundred and twenty three sixth-grade students with a wide range of reading abilities were assigned three different reading tasks: to read for fun, to learn about the topic of the text, and to read for text comprehension. Results suggested that students who read for topic acquired more words than those who read for text comprehension, who in turn out-performed those who read for fun. Moreover, low-ability readers were found to rarely learn any words incidentally. Therefore, the researchers concluded that more aids in addition to simply extensive reading should be provided for low-ability readers to enlarge their vocabulary size.

Pulido (2003) mainly examined incidental vocabulary acquisition from the perspectives of L2 reading proficiency, L2 passage sight vocabulary, and topic familiarity. The results showed that L2 reading proficiency and L2 passage sight vocabulary have strong positive effects on incidental vocabulary acquisition. The learners with better L2 reading proficiency and more L2 passage sight vocabulary acquire more new words incidentally than those with poor L2 reading proficiency and less L2 passage sight vocabulary. Moreover, topic familiarity also affected incidental vocabulary acquisition through reading. The more familiar the learners are towards the reading materials, the more words they can get and retain.

In China, researchers have also put much emphasis on the studies of incidental vocabulary acquisition through reading.

Gai (2003a) made an experiment among English majors. Students were divided into two groups according to the different reading tasks. The first group was asked to answer questions after reading, and the second group was required to retell the main idea of the text after reading. The study showed that the second group performed 
better than the first group in both of the immediate and delayed vocabulary tests.

Huang (2004) conducted a study by comparing three different reading tasks: multiple-choice, filling the gaps with the target words and making sentences with the target words. It turned out that the task of making sentences with target words resulted in better retention of the words than the task of filling gaps with target words and task of multiple-choice. The result of her study supported the Involvement Load Hypothesis, that was, the greater the involvement load, the better the retention.

$\mathrm{Lu}$ (2006) also examined the effect of reading tasks with different involvement loads on the acquisition of English words. The results showed that the group who finished the task of reading and sentence writing produced better results than the group who finished the task of reading and answering the comprehension questions.

Liu (2008) also conducted an experiment to testify the involvement load hypothesis. In her experiment, 81 non English majors were divided into four groups to finish four different reading tasks: reading and answering questions (the target words were provided with Chinese equivalents and related to the questions), reading and completing a summary (the target words were provided with Chinese equivalents and related to the exercise), reading and translating sentences (the target words were not provided with Chinese equivalents but they were related to the task), and reading and translating Chinese sentences (the target words were not provided with Chinese equivalent words in the passage but they were required to be translated in each sentence respectively). This result conformed to Laufer's Involvement Load Hypothesis. In addition, she pointed out that learning habits, learning attitude, guessing ability and learning initiative also affect incidental vocabulary acquisition

\subsection{Studies of Effect of Writing on Incidental Vocabulary Acquisition}

There are also some studies of incidental vocabulary acquisition through writing tasks, and most of them were conducted by comparing writing tasks with other tasks, especially reading tasks.

Hulstijin and Trompetter (1998) found that it was more effective to use the new words looked up in an L1-L2 dictionary to write a composition than use the words to do comprehension tasks.

Cheryl, Sagers and LaPorte (1999) observed nine advanced university EFL learners' incidental vocabulary acquisition from oral and written dialogue journals over a semester's time. The result showed that learners could learn new words through both oral and written journals. Meanwhile, they also found that words appeared in the oral journals could be better acquired and used in the written journals subsequently.

Walker (2001, cited in Gai, 2003b) made a comparison between "writing" and "talking game" in terms of vocabulary acquisition. Two parallel classes participated in this experiment. One class was asked to write a composition by using the target words. The other class was first required to guess the meanings of the target words in several sentences according to the context and then use those words in a talking game. Two weeks later, both classes were asked to write down the meanings of the target words in the delayed vocabulary test. It turned out that the class who finished the "talking game" had better retention of the target words than the other class.

Laufer and Hulstijn (2001) studied the effects of writing and reading on the incidental vocabulary acquisition. The findings showed that writing was more effective for vocabulary retention than reading because writing involved a higher involvement load according to the Involvement Load Hypothesis.

However, in China, there are few empirical studies exploring the effect of writing task on incidental vocabulary acquisition.

Kong (2005) found that the summary writing task was more effective than the reading comprehension task and blanks filling task.

Yin (2007) conducted an experiment among English majors. Seventy-three students were divided into three groups: reading comprehension group, summary writing group and free writing group to finish the three tasks. The study showed that the free writing group had better retention of the target words than the summary writing and comprehension group in both the immediate and delayed vocabulary tests.

\subsection{Studies of Effect of Listening and Speaking on Incidental Vocabulary Acquisition}

There are fewer empirical studies of incidental vocabulary acquisition through merely listening, because listening and speaking are inseparable. Researchers use "retelling" to investigate vocabulary acquisition (Gai, 2003b). Several learners in turn are required to retell the same paragraph. By continuously retelling and questioning, learners can acquire the vocabulary. However, in contrast to the abundant source of research on incidental vocabulary acquisition through reading, there are very few studies referring to listening and speaking experiment both at home and abroad. 
Newton (1995) conducted an experiment of incidental vocabulary acquisition through speaking. In the pretest, among 111 words, $35 \%$ were familiar by all the participants, $54 \%$ were known by one or two participants, and the remaining $11 \%$ were unknown by all the participants. All the words appeared in the text. Participants were divided into groups to discuss the theme of the text. The study showed that the words which were talked about were better acquired by the participants than the not-talked-about words. And interestingly, not only the students who were involved in the discussion but also the people who stood by and didn't have the discussion acquired the words. Therefore, it proved that vocabulary could be acquired through listening.

Vidal (2003) made an experiment through academic listening. The result showed that attending full-time English lectures had great effect on incidental vocabulary acquisition.

$\mathrm{Fu}$ and Chao (2006) compared the effects of three input ways on incidental vocabulary acquisition: listening, reading, and the combination of listening and reading. The result showed that the listening group was better at identifying the pronunciation of the words while the listening and reading group outperformed the other two groups on vocabulary acquisition.

\subsection{Studies of Effect of Translation on Incidental Vocabulary Acquisition}

More and more second language acquisition researchers and teachers have realized the natural advantages of translation in second language acquisition (Hulstijn, 1993; Knight, 1994; Prince, 1995; Chun \& Plass, 1996; Laufer \& Shmueli, 1997; Grace, 1998). Their studies showed that compared with picture illustration, provision of sample sentences and so on, translation was more effective in vocabulary acquisition. What's more, Nation (2001, p. 351) further proposed that translation was an effective way to measure the learners' receptive as well as productive knowledge of vocabulary. When talking about six misunderstandings of vocabulary acquisition, Folse (2004, p. 58) strongly disagreed with one of the misunderstandings, i.e., the students should be prevented from learning vocabulary by translation. He pointed out that translation was actually one of the effective ways to second language vocabulary acquisition. However, up to now, the author hasn't found any empirical studies of incidental vocabulary acquisition through merely translation tasks. A fewer studies were conducted by comparing translation tasks with other tasks, especially reading tasks.

Laufer and Hulstijn (2005, p. 286) questioned the statement that reading was one of the most effective ways for vocabulary acquisition and she made an explorative study by comparing the different effects of translation and reading comprehension on vocabulary size. The subjects were 48 Israeli middle school students whose mother tongue was Hebrew. They were divided into reading group and translation group. It turned out that translation group performed better than reading group in vocabulary acquisition.

Mo (2006) made a study of the effects of reading task on senior students' incidental vocabulary acquisition. In his experiment, two classes were required to read the same reading material. The difference was that the first class was required to answer the questions after the reading while the second class was asked to translate the material into Chinese. The study showed that the class who translated the material acquired larger vocabulary than the class who answered the question.

Zhang (2007) also made a study of the effects of reading task on senior students' incidental vocabulary acquisition. The difference was that there were four different reading tasks in his experiment: 1) reading and answering the questions (words in the passage are noted, bolded but unrelated to the question); 2) reading and answering the questions (target words in the passage are noted and related to the question); 3) reading and completing the sentences (words in the passage are noted and related to the requirement); and 4) reading and translating the underlined sentences (words in the passage are not noted but related to the task). The result revealed that although the involvement load of task four was supposed to be the highest, the participants avoided guessing the meanings of the target words when translating sentences, their acquisition of the target words became the worst.

Huang (2008) made an exploratory study which probed into the correlation between bilingual translation activities and the acquisition of ESL single words and collocations. One group of a Chinese agricultural university EFL learners were exposed to the target lexical items by reading a text and answering comprehension questions followed by theme discussion. Another group of the same background and language proficiency in L1 and L2 read the same text, but were also given two translation activities during which the target items were compared with their Chinese "equivalents". After the completion of the tasks, the two groups were tested on the retention of the target items by two tests. The "reading + translation" group outperformed the "reading + discussion" group on both tests and on productive collocation acquisition in particular. 


\subsection{A New Perspective for the Study on Incidental Vocabulary Acquisition}

The previous related studies mentioned above have revealed that different tasks have different effects on incidental vocabulary acquisition. However, in terms of translation, fewer studies were conducted by comparing translation tasks with other tasks. Almost no research has been undertaken to compare two different translation tasks together. Therefore, the author herself made a tentative study on the effect of different translation tasks on incidental vocabulary acquisition. Two parallel groups were asked to finish Chinese-to-English translation task and English-to-Chinese translation task respectively. The result showed that both Chinese-to-English translation task and English-to-Chinese translation task caused incidental vocabulary acquisition. What's more, there was a significant difference between Chinese-to-English translation class and English-to-Chinese translation class in both immediate and delayed retention of incidental vocabulary acquisition, which suggests that Chinese-to-English translation task is more effective than English-to-Chinese translation task in incidental vocabulary acquisition. This study reveals that in addition to the results shown in previous studies that vocabulary can be acquired incidentally through reading, writing, speaking and listening, it can also be acquired incidentally through translation, which expands the scope of incidental vocabulary acquisition.

\section{Conclusion}

Studies of incidental vocabulary acquisition in second language learning have gained increasing attention both at home and abroad. By reviewing the empirical studies on the effect of different tasks on incidental vocabulary acquisition, it could be seen that a vast number of studies were conducted to show EFL learners could acquire new words incidentally through reading, especially to testify the involvement load hypothesis. There are comparatively fewer empirical studies from the perspectives of listening, speaking, writing and translation. Also, in those empirical studies, only the learners' receptive knowledge of vocabulary is measured with their productive knowledge of vocabulary unmeasured. Thus it calls for further study.

\section{References}

Cheryl, B., Sager, S. L., \& LaPorte, C. (1999). Incidental vocabulary acquisition from oral and written dialogue journals. Studies in Second Language Acquisition, 21, 259-283.

Cho, K., \& Krashen, S. D. (1994). Acquisition of vocabulary from the Sweet Valley Kids Series: Adult ESL acquisition. Journal of Reading, 37, 662-667.

Chun, D., \& Plass, J. (1996). Effects of multimedia annotations on vocabulary acquisition. The Modern Language Journal, 80(2), 183-199. http://dx.doi.org/10.1111/j.1540-4781.1996.tb01159.x

Craik, F. I. M., \& Lockhart, R. S. (1972). Depth of Processing: A framework for memory research. Journal of Verbal Learning and Verbal Behavior, 11, 671-684. http://dx.doi.org/10.1016/S0022-5371(72)80001-X

Elley, W. (1991). Acquiring Literacy in a Second Language: The Effect of Book-Based Programs. Language Learning, 41(3), 375-411. http://dx.doi.org/10.1111/j.1467-1770.1991.tb00611.x

Ellis, R., \& He, X. (1999). The roles of modified input and output in the incidental acquisition of word meanings. Studies in Second Language Acquisition, 21, 285. http://dx.doi.org/10.1017/S0272263199002077

Folse, K. S. (2004). Vocabulary Myths. Michigan: University of Michigan Press.

Fu, C. Y., \& Chao, C. X. (2006). Research into the Influence of Different Input Methods on the Acquisition Effect of English Listening Vocabulary. Journal of Xinyu College, 3, 77-78.

Gai, S. H. (2003a). An empirical study of English majors' incidental vocabulary acquisition. Foreign Language Teaching and Research, 35(4), 282-286.

Gai, S. H. (2003b). A review of incidental vocabulary acquisition. Journal of PLA University of Foreign Languages, 26(2), 73-76.

Grace, C. (1998). Retention of word meanings inferred from context and sentence-level translations: Implications for the design of beginning-level CALL software. The Modern Language Journal, 82(4), 533544. http://dx.doi.org/10.1111/j.1540-4781.1998.tb05541.x

Huckin, T., \& Coady, J. (1999). Incidental vocabulary acquisition in a second language: A review. Studies in Second Language Acquisition, 21, 181-193. http://dx.doi.org/10.1017/s0272263199002028

Hulstijn, J. (1993). When do foreign language readers look up the meaning of unfamiliar words? The influence of task and learner variables. The Modern Language Journal, 77(2), 139-147. http://dx.doi.org/10.1111/j.1540-4781.1993.tb01957.x 
Hulstijn, J. H., \& Trompetter, P. (1998). Incidental learning of second language vocabulary in computer-assisted reading and writing tasks. In D. Albrechtsen, B. Henriksen, L. M. Mees, \& E. Poulsen (Eds.), Perspectives on foreign and second language pedagogy (pp. 191-200). Odense, Denmark: Odense University Press.

Huang, R. Y. (2008). An exploratory study on the correlation between bilingual translation activities and the acquisition of ESL words and collocations. Journal of Xi'an International Studies University, 16(3), 49-53.

Huang, Y. (2004). Testing the Involvement Load Hypothesis: Effects of Reading-Based Tasks on Vocabulary Retention by Chinese FEL learners. Modern Foreign Languages, 27(4), 386-393.

Izumi, Shinichi, \& Bigelow, M. (2000). Does output promote noticing and second language acquisition? TESOL Quarterly, 34(2), 239-273. http://dx.doi.org/10.2307/3587952

Knight, S. (1994). Dictionary use while reading: The effects on comprehension and vocabulary acquisition for students of different verbal abilities. The Modern Language Journal, 78(3), 285-299. http://dx.doi.org/10.1111/j.1540-4781.1994.tb02043.x

Kong, X. Y. (2005). Incidental Second Language Vocabulary Acquisition: Some Empirical Evidence for Task-Induced Vocabulary Acquisition (M.A. dissertation). Tianjin Foreign Studies University, Tianjin, China.

Laufer, B., \& Hulstijn, J. H. (2001). Incidental vocabulary acquisition in a second language: The construct of task-induced involvement. Applied Linguistics, 22(1), 401-413. http://dx.doi.org/10.1093/applin/22.1.1

Laufer, B., \& Hulstijn, J. (2005). Investigations in Instructed Second Language Acquisition. Mouton de Gruyter.

Laufer, B., \& Shmueli, K. (1997). Memorizing new words: Does teaching have anything to do with it? RELC Journal, 28(1), 89-108. http://dx.doi.org/10.1177/003368829702800106

Liu, J. P. (2008). A Study on the Effects of Different Reading Tasks on Incidental Vocabulary Acquisition (M.A. dissertation). Jiangxi Normal University, Nanchang, China.

Lu, X. X. (2006). An Experimental Study on the Effect of Reading Task on L2 Incidental Vocabulary Acquisition (M.A. dissertation). Wuhan University of Technology, Wuhan, China.

Mayumi, T. (2006). From the Involvement Load Hypothesis: An Inquiry into Vocabulary Learning. Retrieved July 10, 2010, from http://cicero.u-bunkyo.ac.jp/lib/kiyo/fsel12006/EIBUN175_184.pdf

Mo, J. P. (2006). The Effects of Reading Tasks on Senior Students' Incidental Vocabulary Acquisition (M.A. dissertation). Northwest Normal University, Lanzhou, China.

Nagy, W. E., Anderson, R. C., \& Herman, P. A. (1987). Learning word meanings from context during normal $\begin{array}{llll}\text { reading. American Educational Research } & \text { Journal, 237-270. }\end{array}$ http://dx.doi.org/10.3102/00028312024002237

Nagy, W. E., Herman, P. A., \& Anderson, R. C. (1985). Learning words from context. Reading Research Quarterly, 20, 233-253. http://dx.doi.org/10.2307/747758

Nation, I. S. P. (2001). Learning Vocabulary in Another Language. Cambridge: Cambridge University Press. http://dx.doi.org/10.1017/CBO9781139524759

Newton, J. (1995). Task-based interaction and incidental vocabulary learning: A case study. Second Language Research, 11, 159-177. http://dx.doi.org/10.1177/026765839501100207

Paribakht, T. S., \& Wesche, M. (1996). Enhancing vocabulary acquisition through reading: A hierarchy of text-related exercise types. Canadian Modern Language Review, 52, 155-178.

Prince, P. (1995). Second language vocabulary learning: The role of context versus translations as a function of $\begin{array}{lllll}\text { proficiency. The Modern } & \text { Language Journal, }\end{array}$ http://dx.doi.org/10.1111/j.1540-4781.1996.tb05468.x

Pulido, D. (2003). Modeling the role of second language proficiency and topic familiarity in second language incidental vocabulary acquisition through reading. Language Learning, 53(2), 233-284. http://dx.doi.org/10.1111/1467-9922.00217

Swain, M. (1985). Communicative competence: Some roles of comprehensible input and comprehensible output in its development. In S. Gass, \& C. Madden (Eds.), Input in Second Language Acquisition (p. 253). New York: Newbury House.

Swanborn, M. S. L., \& de Glopper, K. (2002). Impact of reading purpose on incidental word learning from context. Language Learning, 52, 95-117. http://dx.doi.org/10.1111/1467-9922.00178 
Vidal, K. (2003). Academic listening: A source of vocabulary acquisition? Applied Linguistics, 24, 56-89. http://dx.doi.org/10.1093/applin/24.1.56

Yin, X. J. (2007). Learning Task Effects on Incidental Vocabulary Acquisition for English Majors (M.A. dissertation). Chongqing University, Chongqing, China.

Zhang, M. (2007). The Effects of Reading Tasks on Incidental Vocabulary Acquisition (M.A. dissertation). Capital Normal University, Beijing, China.

\section{Copyrights}

Copyright for this article is retained by the author(s), with first publication rights granted to the journal.

This is an open-access article distributed under the terms and conditions of the Creative Commons Attribution license (http://creativecommons.org/licenses/by/3.0/). 